\title{
The Action of Mendelian Genes in Human Diploid Cell Strains '
}

\author{
ROBERT S. KROOTH AND ELIZABETH K. SELL $~ 2$ \\ Lawrence D. Buhl Center for Human Genetics, Department of Human \\ Genetics, University of Michigan Medical School, \\ Ann Arbor, Michigan 48104
}

\begin{abstract}
Some of the cells of every human being will grow outside the body as microorganisms. It is possible to show, in a variety of ways, that these cells resemble genetically the individual from whom they were obtained. Over 35 inherited human diseases and anomalies can now be studied in such cell lines.

Human diploid cell strains, biochemically marked by one or more mutant Mendelian genes, have proven particularly useful for the study of gene action in man and for the detection of genetic changes such as mutation and somatic cell hybridization. In addition, the strains have a number of clinical applications, including the antenatal diagnosis of inherited disease.

The failure of cultured human cells to display their phenotype at most loci continues to restrict their use in both genetics and medicine. There are reasons for hoping that this difficulty will eventually be solved, and some experiments bearing on the problem are already feasible.
\end{abstract}

To study genetics, one must start with hereditary variation. In cell culture, this means one must have, as a minimum, two different strains of cells which differ from one another in at least one attribute. Moreover, the difference must be hereditary over somatic generations.

The initial problem of human cell genetics, therefore, has been to identify or generate this kind of variation. Two principal methods have been used to obtain lines of human cells that have some distinctive and hereditary attribute. The first method is to select infrequent cells, from a population which differs in a known way from the majority of the cells. For example, nearly all cells exposed to the synthetic analogue 8-azaguanine are killed by this agent, but, over a wide range of doses, a few are not (Szybalski and Szybalska, '62; inter aliae). The surviving cells are resistant to the drug, even if they are grown in its absence for an extended period of time. In most cases, the resistant subline is deficient in an enzyme which apparently converts 8-azaguanine to the corresponding ribotide (Brockman et al., '61; inter aliae). It is likely to be this ribotide, rather than the free base, which is cytotoxic. In any case, such an experiment frequently leads to the isolation of a variant subline; in this case as well as in several others, an enzyme deficiency is associated with the ability of the cell to survive in the selective medium. Indeed, there are several general methods for preferentially favoring the growth of auxotrophic mammalian cells (Hooper and DeMars, '60; Kao and Puck, '68; Pollack, Green and Todaro, '68). Most such auxotrophs may be presumed to be deficient in one or more enzyme activities.

The second method for obtaining variant lines of human cells is quite different. One begins by selecting donors (rather than cells ) who are known to carry genes which affect molecules normally present in cultured cells (Krooth and Weinberg, '61). The Mendelian basis for the cellular phenotype is shown by developing strains from various persons in the same family.

There are important differences between the first and second method. In the first method, the variant line and the line with which it is compared usually come from the same donor. In the second method, the donors are different. It can be argued that variants isolated by the first method are

\footnotetext{
1 The original investigations reported in this paper were supported by NIH Research grant 1-P01-15419-03. ${ }^{2}{ }^{2}$ Supported by NIH Training grant 5-T01-GM-00071-
} 
likely to differ from the parental line at only a single locus. On the other hand, when a variant isolated by the second method is compared with a strain isolated from a normal donor, the two strains probably differ at many loci, for the genetic polymorphism of human populations is very rich (Harris, '66; Lewontin, '67). The advantage of the second method of course is that one can prove by family studies that the cell attribute is hereditary over the germ line, as well as over the somatic one. From such studies, one can frequently conclude that the attribute is controlled within each family by a single locus. If cell strains from several different unrelated patients all differ from normal strains in the same way, one can argue that normal variation at loci other than the one being studied is irrelevant.

As a rule, each method involves the use of a different kind of cell. The first method has been used successfully with heteronuclear cell lines, while the second method employs homonuclear lines. The contrasting properties of these two kinds of cell lines have been reviewed elsewhere (Krooth, Darlington and Velazquez, '68). Their main features, which are relevant to this discussion, are as follows: Human heteronuclear lines show marked variation from cell to cell in chromosome complement, are capable of indefinite growth in vitro, and usually clone with high efficiency. Human heteronuclear lines are rarely isolated. Indeed, recent evidence suggests that many of the lines commonly used in experiments, and thought to have independent origins, may in fact all be derived from a single donor (Gartler, '67). Most human heteronuclear lines seem to have been isolated from tissue involved in a cancerous process.

Human homonuclear lines, on the other hand, usually show very little variation from cell to cell in chromosome complement - no more than is found in most intact tissues. They grow in vitro for only about six months to a year, and are difficult to clone with high efficiency except perhaps very shortly after their isolation from the explant. An important feature of homonuclear lines is that they can easily be developed from virtually any donor. ${ }^{3}$

The reason that the two methods have each been used with a different kind of cell is probably related to the biology of the cells. Since homonuclear cells, unlike heteronuclear ones, usually do not clone with high efficiency, it can be difficult to select an infrequent cell from the population. The variant cell may not be able to generate a colony when all the other cells have been eliminated by the selective system. Human heteronuclear lines, though they usually can be cloned with high efficiency, are rarely isolated. Hence, the probability of developing a heteronuclear line from a donor of an appropriate genotype is small.

A disappointing feature of cultured human cells is that they do not usually perform the tissue-specific functions of the organ from which they were isolated. The reason for this phenomenon is unknown, and a detailed discussion of the matter is outside the limits of this review. However, it seems likely that there are at least two separate mechanisms involved. In the case of human heteronuclear lines, the apparent failure of the cells to perform tissue-specific functions may be related to the anaplasia of the carcinomas from which they were isolated. In addition, most human heteronuclear lines appear to have been developed from carcinomas of the cervix, and have not been tested for their ability to perform a biochemical function peculiar to the uterine cervix. In the case of human homonuclear cell lines, the mechanism is likely to be different. These cells have a fusiform morphology and engage in the de novo synthesis of collagen (Green, Goldberg and Todaro, '66) and mucopolysaccharides (Fratantoni et al., '68). Hence, it seems likely that they are descended from the fibroblasts of intact tissues. Apparently, with existing methods only this type of human cell is capable of sustained growth in culture - at least in the case of normal solid tissues biopsied subsequent to birth. Perhaps the same is true of other animals. The type of cell recovered in culture seems surprisingly independent of the organ whose tissue is sampled. Hence, it is likely that the human cell which grows in vitro is a fibroblast - a stromal element

3 It must be emphasized that the rules which govern the biology of cultured human cells do not necessarily apply to the cells of other mammalian species (Todaro and Green, '63; Green and Todaro, '63; Bayreuther, '64; Herzenberg, '64). 
which is ubiquitous. It is present in all organs but is the characteristic cell in none. ${ }^{4}$

When we began to study gene action in human diploid cells, we tentatively formulated a rule that if an enzyme or other molecule were ubiquitous - if it were present in all tissues - it would be found in cultured homonuclear cells. The presence of the molecule would presumably then not depend on which way the cell had differentiated (Krooth and Weinberg, '61; Krooth, '65). In practice, no enzyme has been studied in all tissues, and we used the rule-of-thumb that if the enzyme were present in peripheral blood cells and a parenchymatous organ other than spleen, it was likely to be ubiquitous and therefore present in cultured cells (Krooth, '64a, '65). As far as is known, this rule still seems to hold, but its converse does not. Some molecules which are not ubiquitous are indeed present in cultured cells (Uhlendorf and Mudd, '68), perhaps because the human homonuclear cell is descended from a fibroblast - a specialized cell which performs its own peculiar functions. At present, it seems unlikely that the cultured human homonuclear cell is "dedifferentiated," i.e., derived from parenchymatous cells that have lost the distinctive properties which give them their identity.

In table 1, we have listed many of the mutant Mendelian genes which have been shown to affect specific molecules in the cultured human cell. ${ }^{5}$ There are at present over 35 such genes, and they probably reflect mutations at 30 different loci. Seven of the genes are on the X-chromosome, while the remainder are autosomal. The clinical phenotypes associated with these genes vary from quite severe disorders, such as the Lesch-Nyhan Syndrome or cystinosis, to biochemical traits like the electrophoretic variants of glucose-6-phosphate dehydrogenase or lactic acid dehydrogenase that produce no known signs or symptoms. The mutant cellular phenotypes associated with the genes listed in table 1 include disorders of carbohydrate, amino acid, lipid and nucleotide metabolism. For five of the genes, selective media which prevent the growth of mutant homozygous cells have been formulated. These genes are the ones for galactosemia (Krooth and Weinberg, '61; Krooth, '66a), orotic aci- duria (Krooth, '64b,'66a), citrullinemia (Tedesco and Mellman, '67), arginosuccinic aciduria (Shih, Littlefield and Moser, '69) and the Lesch-Nyhan Syndrome (Felix and DeMars, '69; Siniscalco et al., '69; inter aliae). In the case of this latter condition, a medium which will select in favor of mutant homozygous cells, and against normal cells, has also been developed (Albertini and DeMars, '70).

\section{Examples of gene action in diploid cell strains}

\section{a. Galactosemia}

Galactosemia is a rare autosomal recessive disease. Affected patients have acute milk intolerance during infancy, cataracts, and other signs and symptoms (Isselbacher, '66). The condition is treated by withholding milk from the diet, and if untreated is frequently fatal.

The erythrocytes and other tissues of affected patients have no detectable activity for galactose-1-phosphate:UDP glucose uridyltransferase (cf. Isselbacher, '66). This enzyme catalyzes the second step in the Leloir pathway - a pathway which effects the conversion of galactose to glucose.

Cultured cells from mutant homozygous persons are unable to liberate $\mathrm{C}^{14} \mathrm{O}_{2}$ from galactose-1-C ${ }^{\mathrm{i} 4}$, whereas cells from normal and heterozygous persons can (Krooth and Weinberg, '61). Similarly, when cell ex-

4 Moore and his associates have recently demonstrated that lymphoblastic cell lines can frequently be isolated from the peripheral blood of normal persons (Moore and McLimans, '68. Moore, Porter and Huang, 69) These lines are diploid, grow in vitro indefinitely, and synthesize immunoglobulins (Fahey et al., '66). Hence, another class of human cells and perhaps another class of tissue-specific loci are now available for microbiological experiments. Very recently, Mendelian mutations (at 2 different loci) affecting the phenotype of these cells have been described (Conover et al., '70; Choi and Bloom, '70).

5 Table 1 is of course a summary of the work of many different Iaboratories. A bibliography for each of the entries in table 1 is given elsewhere (Krooth, ' 69 a) except for the most recently described cellular phenotypes. These are galactokinase deficiency (Mayes and Guthrie, '68; Sell, '70), Gaucher's disease (Uhlen

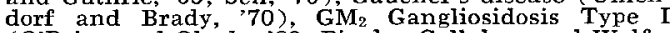
(O'Brien and Okada, '69; Pinsky, Callahan and Wolfe, '68) GM. Gangliosidosis Type II (O'Brien et al., '70), $\mathrm{GM}_{2}$ Gangliosidosis Type III ( $i$ bid.), GM G Gangliosidosis Type I ( Sloan et al.,'69), GM 1 Gangliosidosis Type II (O'Brien et al., '70; Wolfe et al., '70), glycogen storage disease Type III (Tustice et al., '69), Scheie's Syndrome (Wiesmann and Neufeld, '70), Sanfilippo Syndrome (ibid.), and xeroderma pigmentosa (Cleaver, '68; Setlow et al., "69). In addition, there has been important new work with several of the has been important new work with several of the and Hunter's Syndrome (Fratantoni, Hall and Neufeld, '68; Fratantoni, Hall and Neufeld, '69). 
TABLE 1

Some genetic abnormalities that affect specific molecules present in the cultured human homonuclear cell

\begin{tabular}{|c|c|c|}
\hline Disease or variant & Affected molecule & Genetics \\
\hline $\begin{array}{l}\text { "A" electrophoretic variant of } \\
\text { glucose-6-phosphate } \\
\text { dehydrogenase (G-6-PD) }\end{array}$ & $\begin{array}{l}\text { Glucose-6-phosphate } \\
\text { dehydrogenase }\end{array}$ & Sex-linked co-dominant \\
\hline Acatalasia I (Japanese variant) & Catalase & Autosomal recessive \\
\hline Acatalasia II (Swiss variant) & Catalase & Autosomal recessive \\
\hline Arginosuccinic aciduria & Arginosuccinase & Autosomal recessive \\
\hline Branched-chain ketonuria & Uncertain & Autosomal recessive \\
\hline Citrullinemia & Arginosuccinate synthetase & Autosomal recessive \\
\hline Cystinosis & Uncertain & Autosomal recessive \\
\hline $\begin{array}{l}\text { Electrophoretic variant of } \\
\text { phosphoglucomutase }\end{array}$ & Phosphoglucomutase & Autosomal co-dominant \\
\hline $\begin{array}{l}\text { Electrophoretic variant of } \\
\text { lactic dehydrogenase }\end{array}$ & Lactic acid dehydrogenase & Autosomal co-dominant \\
\hline $\begin{array}{l}\text { Electrophoretic variants of } \\
\text { 6-phosphoglucuronic acid } \\
\text { dehydrogenase }\end{array}$ & 6-phosphoglucuronic acid & Autosomal co-dominant \\
\hline $\begin{array}{l}\text { Familial nonspherocytic } \\
\text { hemolytic anemia }\end{array}$ & $\begin{array}{l}\text { Glucose-6-phosphate } \\
\text { dehydrogenase }\end{array}$ & Sex-linked recessive \\
\hline $\begin{array}{l}\text { GM }_{1} \text { Gangliosidosis Type I } \\
\quad \text { (Generalized Gangliosidosis) }\end{array}$ & $\begin{array}{l}\text { Absence of B-galactosidase } \\
\text { A, B, C }\end{array}$ & Autosomal recessive \\
\hline $\begin{array}{l}\text { GM }_{1} \text { Gangliosidosis Type II } \\
\text { (Juvenile GM } \\
\text { Gangliosidosis) }\end{array}$ & $\begin{array}{l}\text { Absence of B-galactosidase } \\
\text { B and C }\end{array}$ & Autosomal recessive \\
\hline $\begin{array}{l}\mathrm{GM}_{2} \text { Gangliosidosis Type I } \\
\text { (Tay-Sachs Disease) }\end{array}$ & Absence of hexosaminidase A & Autosomal recessive \\
\hline $\begin{array}{l}\mathrm{GM}_{2} \text { Gangliosidosis Type II } \\
\text { (Sandhoff's Disease) }\end{array}$ & $\begin{array}{l}\text { Absence of hexoaminidase } \\
\text { A and } B\end{array}$ & Autosomal recessive \\
\hline $\begin{array}{l}\mathrm{GM}_{2} \text { Gangliosidosis Type III } \\
\text { (Juvenile } \mathrm{GM}_{2} \\
\text { Gangliosidosis) }\end{array}$ & $\begin{array}{r}\text { Partial deficiency of } \\
\text { hexosaminidase } A\end{array}$ & Autosomal recessive \\
\hline $\begin{array}{l}\text { G-6-PD deficiency } \\
\text { (Mediterranean type) }\end{array}$ & $\begin{array}{l}\text { Glucose-6-phosphate } \\
\text { dehydrogenase }\end{array}$ & Sex-linked recessive \\
\hline $\begin{array}{l}\text { G-6-PD deficiency } \\
\text { (Negro type) }\end{array}$ & $\begin{array}{l}\text { Glucose-6-phosphate } \\
\text { dehydrogenase }\end{array}$ & Sex-linked recessive \\
\hline Galactokinase deficiency & Galactokinase & Autosomal recessive \\
\hline Galactosemia & $\begin{array}{l}\text { Uridine diphosphogalactose } \\
\text { transferase }\end{array}$ & Autosomal recessive \\
\hline Gaucher disease & Glucoceribosidase & Autosomal recessive \\
\hline $\begin{array}{l}\text { Glycogen storage disease } \\
\text { (Cori type II) }\end{array}$ & Lysosomal $a-1,4$-glucosidase & Autosomal recessive \\
\hline $\begin{array}{l}\text { Glycogen storage disease } \\
\text { (Type III) }\end{array}$ & Amylo-1-6-glucosidase & $\begin{array}{l}\text { Probably autosomal } \\
\text { recessive }\end{array}$ \\
\hline Homocystinuria & Cystathionine synthetase & Autosomal recessive \\
\hline
\end{tabular}


TABLE 1 (continued)

\begin{tabular}{|c|c|c|}
\hline Disease or variant & Affected molecule & Genetics \\
\hline Hunter's syndrome & $\begin{array}{l}\text { Uncertain (Macromolecule } \\
\text { which influences cellular con- } \\
\text { tent of mucopolysaccharides) }\end{array}$ & Sex-linked recessive \\
\hline Hurler's syndrome & $\begin{array}{l}\text { Uncertain (Macromolecule } \\
\text { which influences cellular con- } \\
\text { tent of mucopolysaccharides) }\end{array}$ & Autosomal recessive \\
\hline "I-cell disease" & $\begin{array}{l}\text { Uncertain (beta-glucuronidase } \\
\text { activity decreased; mucopoly- } \\
\text { saccharide content increased) }\end{array}$ & $\begin{array}{l}\text { Probably autosomal } \\
\text { recessive }\end{array}$ \\
\hline $\begin{array}{l}\text { Infantile metachromatic } \\
\text { leukodystrophy }\end{array}$ & Arylsulfatase A & Autosomal recessive \\
\hline Lesch-Nyhan syndrome & $\begin{array}{l}\text { Hypoxanthine: guanine: } x \text { an- } \\
\text { thine phosphoribosyltrans- } \\
\text { ferase }\end{array}$ & Sex-linked recessive \\
\hline $\begin{array}{l}\text { Madison electrophoretic } \\
\text { variant of glucose-6- } \\
\text { phosphate dehydrogenase }\end{array}$ & $\begin{array}{l}\text { Glucose-6-phosphate } \\
\text { dehydrogenase }\end{array}$ & Sex-linked co-dominant \\
\hline Methylmalonic aciduria & $\begin{array}{l}\text { Uncertain (Defective } \\
\text { Vitamin } B_{12} \text { synthesis) }\end{array}$ & Uncertain \\
\hline Niemann-Pick disease & $\begin{array}{l}\text { Uncertain (Increased cellular } \\
\text { level of sphingomyelin) }\end{array}$ & Autosomal recessive \\
\hline Orotic aciduria & $\begin{array}{l}\text { Orotidine-5'-monophosphate } \\
\text { pyrophosphorylase and } \\
\text { orotidine- } 5^{\prime} \text {-monophosphate } \\
\text { decarboxylase }\end{array}$ & Autosomal recessive \\
\hline Refsum's disease & Phytanic acid a-oxidase & Autosomal recessive \\
\hline Sanfilippo-Syndrome & $\begin{array}{l}\text { Uncertain (Macromolecule } \\
\text { which influences cellular con- } \\
\text { tent of mucopolysaccharides) }\end{array}$ & Autosomal recessive \\
\hline Scheie Syndrome & $\begin{array}{l}\text { Uncertain (Macromolecule } \\
\text { which influences cellular con- } \\
\text { tent of mucopolysaccharides) }\end{array}$ & Autosomal recessive \\
\hline Xeroderma pigmentosa & $\begin{array}{l}\text { Uncertain (Defective excision } \\
\text { repair of DNA) perhaps } \\
\text { an endonuclease }\end{array}$ & Autosomal recessive \\
\hline
\end{tabular}

tracts are assayed, the mutant homozygous strains - unlike normal or heterozygous ones - have little or no activity for the affected enzyme (Russel, '69; Mayes and Guthrie, '68; Tedesco and Mellman,'69).

Galactosemic cells will not grow in a medium in which galactose is the sole hexose present, under circumstances in which normal and heterozygous cells will (Krooth and Weinberg, '61; Krooth, '66a). However, the selective system for this locus works consistently only when the cells are at a high population density. At low population density, a significant fraction of normal or heterozygous cells frequently die in galactose, and the discrimination between the cellular phenotypes on the basis of growth is obscured. ${ }^{6}$ The minimum population density at which the selective system works varies from experiment to experiment, but a confluent monolayer of galactosemic cells will invariably die in galactose, whereas a confluent monolayer of normal or heterozygous cells will invariably survive. The dependence of the selective system for this locus on cell population density may be related to the fact that the specific transferase activity of the

${ }^{6}$ This effect can be minimized somewhat by methods deseribed elsewhere (Krooth, '66). 
cell protein progressively increases with cell population density (Russel, '69).

The competence of a culture to grow in galactose can be predicted from its ability to grow in reduced quantities of glucose. Repeated experiments have shown that only in circumstances where the cells are capable of growth in a medium containing $5 \mathrm{mg}$ per cent glucose will they grow in galactose.

Of course, a system which requires a high cell population density to assess genotype is of little use for the purpose of selecting from the population a rare galactosemic cell that may have changed genetically due to mutation or some other cause. However, even with this limitation, such a system has a certain advantage over enzyme assays or histochemical methods for determining phenotype. The culture, if heterozygous or normal, is not lost to the investigator by the procedure of determining its phenotype. Hence, the system can be used to screen clones (but not to isolate them) on which other procedures can be subsequently performed.

Another curious feature of the selective system for the galactosemia locus is that, at least in our hands, it seems to work consistently only when the medium contains dialyzed human sera. It is often not possible to demonstrate the hexose-dependence of human diploid cell strains in medium containing dialyzed fetal calf sera. Not only do galactosemic cells sometimes grow in galactose, but cells of all genotypes frequently grow in hexose-free medium. When first placed in hexose-free medium, the cells usually cease growth for a few days, and a minority of them may even die, but then, mysteriously, the culture recovers and growth resumes. Albertini and DeMars ("70) have recently commented on the way in which fetal calf serum appears to interfere with another selective system for diploid cell strains. In any event, the selective system for the galactosemic locus, using dialyzed human sera, enables one to determine cellular phenotype when the cells being tested are at a high population density.

\section{b. The Lesch-Nyhan Syndrome and related conditions.}

The Lesch-Nyhan Syndrome (Nyhan et al., '67; Seegmiller, '69) is a rare X-linked disorder of purine metabolism. Affected children produce uric acid at an abnormally rapid rate, and have symptoms secondary to hyperuricemia. They also show evidence of deranged function of the central nervous system, and some of the patients have an anemia as well.

Diploid cell strains (Seegmiller, Rosenbloom and Kelley, '67; Friedman, Seegmiller and Subak-Sharpe, '69) from affected persons have about $1 \%$ of normal activity for hypoxanthine:guanine:xanthine phosphoribosyltransferase (HGPRTase). This enzyme (fig. 1) normally serves the function of converting a purine catabolite (hypoxanthine) to a ribotide (inosine$5^{\prime}$-monophosphate). The ribotide in turn inhibits the first enzyme of purine synthesis - the amidotransferase - and therefore perhaps the rate at which purines are formed. In addition, HGPRTase catalyzes the conversion of guanine to guanine5 -monophosphate, a ribotide which also inhibits the amidotransferase of purine synthesis (cf. Seegmiller, Rosenbloom and Kelley, '67).

One theory of the pathogenesis of the Lesch-Nyhan Syndrome holds that in the absence of activity for the affected enzyme, purine synthesis accelerates since the cell is now less sensitive to the size of the purine pool. The inosinic acid synthesized is catabolized to hypoxanthine, but very little of the hypoxanthine is converted back into inosinic acid because of the enzyme deficiency. Hence, the steady state concentration of inosinic acid in the cell is reduced, and the amidotransferase is released from feedback inhibition. For this reason (according to the theory) the velocity of purine synthesis is accelerated (Rosenbloom et al, '68; Seegmiller, '69). Another possibility (Rosenbloom et al., '68) is related to the fact that PRPP (5phosphoribosyl-1-pyrophosphate) may be a rate-limiting substrate in purine synthesis. In the Lesch-Nyhan Syndrome, the affected enzyme catalyzes a reaction which consumes a significant amount of this compound, and hence one might expect the cellular level of PRPP to be elevated. That indeed is the case (Rosenbloom et al., '68; Greene, Boyle and Seegmiller, '70), and it may be that the increase in PRPP available to serve as a substrate for the amidotrans- 


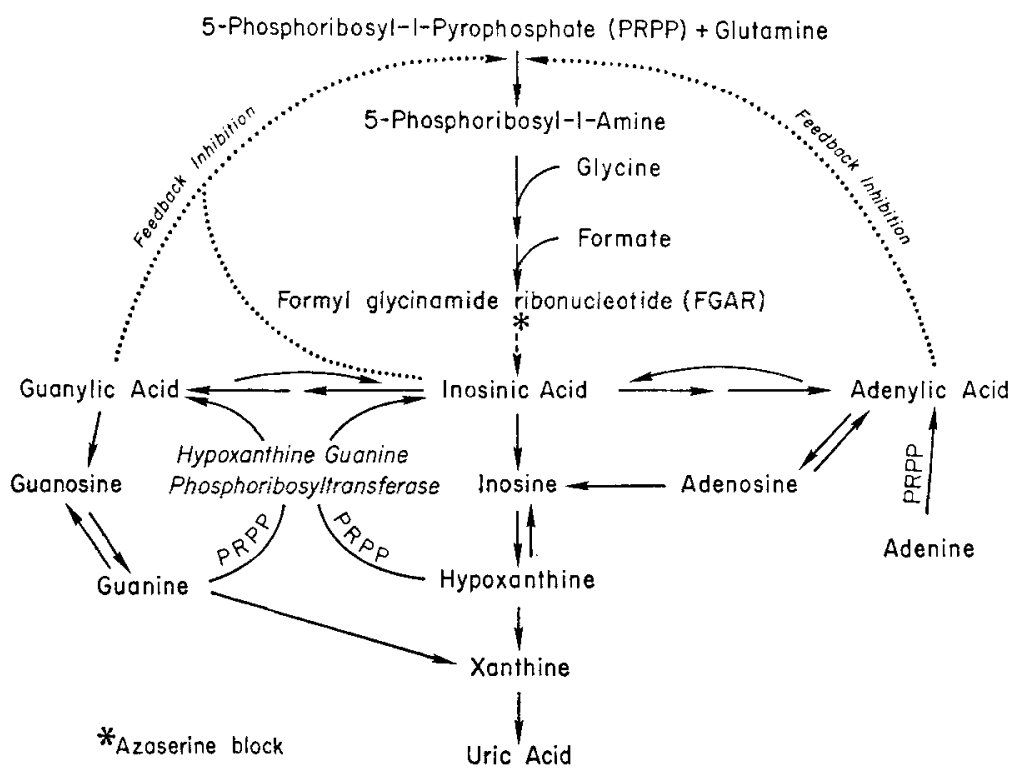

Fig. 1 Purine synthesis and catabolism in man (from Seegmiller, Rosenbloom and Kelley, '67).

ferase is partly - or even mainly - responsible for the acceleration of purine synthesis. Other possibilities, however, are also admissible (Rosenbloom et al., '68).

Diploid cell strains from persons affected with this disease have about three times the normal level of adenine phosphoribosyltransferase (Seegmiller, Rosenbloom and Kelley, '67). Recent evidence suggests that the accumulation of PRPP inside the cell (referred to above) may serve to stabilize this enzyme (Greene, Boyle and Seegmiller, "70). It is also possible that still a third enzyme, inosine kinase, may be affected in the Lesch-Nyhan Syndrome, but evidence on this point is still being accumulated (Friedman, Seegmiller and Subak-Sharpe, '69; Payne et al., '70).

Diploid cell strains from mutant hemizygous males are unable to grow in "HAT" medium, whereas strains from normal persons grow readily in this medium (Siniscalco et al., '69). HAT medium contains hypoxanthine, amethopterin, and thymidine. Amethopterin blocks both de novo purine synthesis and the de novo synthesis of thymidylic acid. Hence, in the presence of amethopterin, normal cells require both thymidine and hypoxanthine. The Lesch.
Nyhan cells fail to grow in HAT medium presumably because their deficiency for HGPRTase prevents them from converting the hypoxanthine in the medium to inosinic acid.

On the other hand, purine analogues, such as 8-azaguanine and 6-mercaptopurine, which prevent the growth of normal cells might be expected to have little or no effect on Lesch-Nyhan cells (Seegmiller, Rosenbloom and Kelley, '67). These fraudulent purines are apparently mistaken by the enzyme (HGPRTase) for utilizeable ones and seem to affect cellular metabolism after they have been converted to the corresponding ribotides. The ribotides then probably inhibit the amidotransferase, and decelerate the velocity of purine synthesis. It has recently been shown that 6-mercaptopurine slows purine synthesis in normal cells but not in LeschNyhan cells (Seegmiller, Rosenbloom and Kelley, '67). Moreover, 8-azaguanine does not inhibit the growth of Lesch-Nyhan cells and indeed can be used to select cells deficient in HGPRTase out of a population of normal diploid cells (Albertini and DeMars, '70).

Lesch-Nyhan cells from at least one patient have other abnormal nutritional 
requirements. The cells will not grow unless the medium is supplemented with either adenine or unusually high concentrations of folic acid (Felix and DeMars, '69). The requirement for adenine probably reflects the fact that the mutant cells are starved for purines, even though they are producing purines at an accelerated rate. Presumably, in the absence of HGPRTase, most of the inosinic acid synthesized is catabolized to oxypurines and is unavailable for DNA and RNA synthesis. Adenine, when converted to AMP by the adenine PRTase, can be subsequently converted to inosinic acid, and thus should serve to increase the steady-state concentration of this vital metabolite. Folic acid may be a rate-limiting factor in purine synthesis. When the medium is supplemented with very high levels of folic acid, the Lesch-Nyhan cells might accelerate purine synthesis even further. Such an acceleration would in turn tend to increase the cellular concentration of inosinic acid. $A$ third and even more surprising nutritional feature of this strain of cells is that their growth is very significantly stimulated by high concentrations of hypoxanthine - the substrate of the affected enzyme. There is, on the face of it, no immediate explanation for this paradoxical result; one might argue that the affinity of the enzyme for substrate has been altered by a structural mutation, so that abnormally large quantities of substrate are required to saturate the enzyme. Alternatively, the fact that hypoxanthine stimulates purine synthesis, in at least one mutant strain, might be the explanation (Rosenbloom et al., '68).

In the case of a severe sex-linked disease, like the Lesch-Nyhan Syndrome, patients from different families may not always be comparable. If every patient with the disease fails to reproduce, onethird of the genes will be eliminated at each generation. The reason for this is that all the mutant genes are on X-chromosomes, and approximately one-third of $\mathrm{X}$-chromosomes are in males. Therefore, one-third of the mutant genes will be in males, and the males will presumably be eliminated by natural selection. Now if the population is in equilibrium with respect to the frequency of the disease, one-third of all new cases should be fresh mutations. These new mutations need not all produce the disease by the same mechanism. The structure of the enzyme may conceivably be altered in different ways, or even, in some instances, through a gene substitution whose effect on catalytic activity is less direct. In any case, such an explanation may account for the clinical differences between patients, such as the presence or absence of anemia. It may also account for certain paradoxes, such as the fact that some strains will not grow in HAT medium while the growth of others is stimulated by hypoxanthine, ${ }^{7}$ or even the possible variation between patients in whether inosine kinase activity is affected by the gene (Friedman, Seegmiller and Subak-Sharpe, '69; Payne et al., '70).

Apart from the Lesch-Nyhan Syndrome, several other disorders associated with deficient HGPRTase activity have been described (Kelley et al., '67; Kelley et al., '69). In these conditions, the enzyme deficiency is less complete than in the LeschNyhan Syndrome. Clinically, the patients are characterized by hyperuricemia, gouty arthritis, and in some cases evidence of mild spinocerebellar disease. The clinical features and the enzyme deficiencies are familial, and have thus far been reported only in males. The family data are consistent with $\mathrm{X}$-linkage of the relevant locus or loci. Studies of the heat-stability of the HGPRTase activities recovered from affected patients suggest that the enzyme molecules are abnormal, and that the abnormality differs from family to family.

These less complete enzyme deficiencies can be detected in cultured fibroblasts (Kelley et al., '69). In addition, fibroblasts from two male, gouty patients - who are not members of the same family - appear to be relatively insensitive to feedback inhibition by exogenous purines (Henderson et al., '68). Cells from these patients do not decelerate purine synthesis, as readily as normal cells, when incubated in a purine-containing medium. Yet the cells formed purine nucleotides from hypoxanthine at a normal rate, implying that HGPRTase was not deficient. Hence, it is

7 This paradox may also be explicable on the basis of the different concentrations of hypoxanthine used by the various authors (Compare siniscalco et al., '69, with Felix and DeMars, '69). 
conceivable that in one or both of these patients the amidotransferase - the first enzyme of the synthetic sequence - is abnormal. If indeed the amidotransferase is affected, the abnormality would presumably be one which diminishes the inhibitory effect of purine ribotides on the catalytic activity of the enzyme.

It is of interest in this connection that there are at least three different diseases which lead to an overproduction of uric acid and which can be recognized and studied in cultured human fibroblasts - a type of cell that in fact lacks xanthine oxidase activity and therefore cannot synthesize uric acid. The reason for this surprising state of affairs is that in these diseases the more basic lesion is an abnormally rapid rate of de novo purine syn- thesis. This anomaly in turn has proven, in each case, to be due to a deficiency or abnormality of an enzyme which fibroblasts contain.

\section{c. Orotic aciduria}

Orotic aciduria is a rare autosomal recessive disorder which is characterized by failure to grow, pancytopenia, and the excretion of extremely large quantities of orotic acid (Smith, Huguley and Bain, '66). Diploid cell strains from affected persons (Krooth, '64b; Howell, Klinenberg and Krooth, '67) have about $1 \%$ of normal activity for the final two sequentially acting enzymes in the synthesis of uridine- $5^{\prime}$ monophosphate (UMP). The enzymes (fig. 2) are orotidine- 5 '-monophosphate (OMP) pyrophosphorylase and OMP decarboxyl-
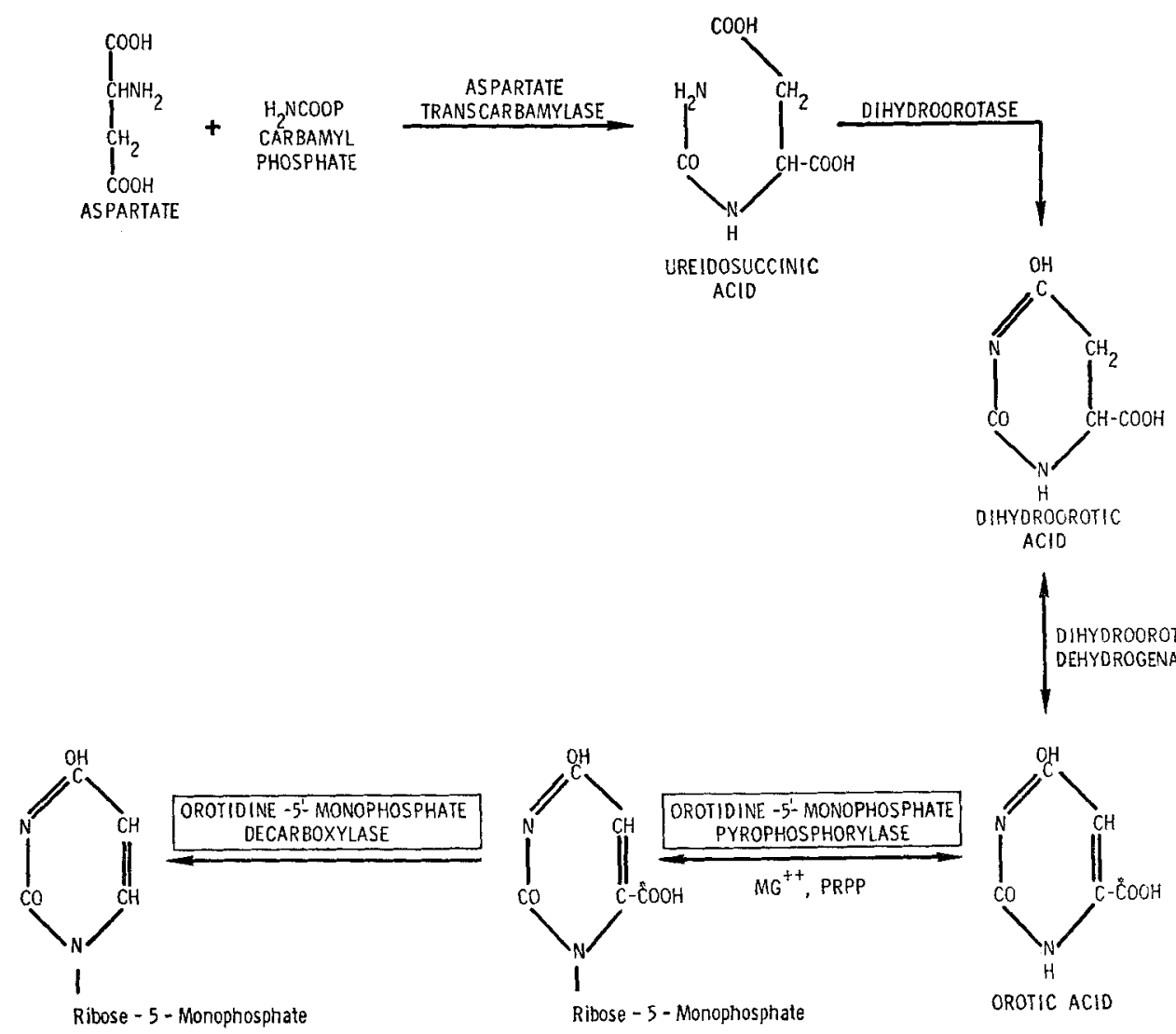

URIDINE -5'- MONOPHOSPHATE

OROTIDINE -5'- MONOPHOSPHATE

(UMP)

(OMP)

Fig. 2 The pathway of de novo pyrimidine synthesis in human diploid cell strains. 
ase. The other enzymes peculiar to the purine pathway appear to be unaffected by the gene (Krooth, '64b; Howell, Klinenberg and Krooth, '67; Smith, Sullivan and Huguley, '61; Wuu and Krooth, '68). Heterozygous persons have only $20 \%$ of normal activity for the two affected enzymes in their erythrocytes (Smith, Sullivan and Huguley, '61; Fallon et al., '63). Heterozygous cell strains also have intermediate levels of activity, although the value, as a percentage of normal, is somewhat variable (Krooth, '64).

Diploid cell strains from affected persons will grow in a minimal medium, but their growth is stimulated if the medium contains uridine or cytidine (Krooth, '64b). However, if a purine or purine riboside is added to the medium, the mutant homozygous cells cease growth after about 72 hours, whereas normal or heterozygous cells are unaffected. The growth of the mutant homozygous cultures is not inhibited by purines or purine ribosides if the medium also contains uridine or cytidine (Krooth, '64b). It can be shown that in the presence of purines or purine ribosides the specific activity of the cell protein for at least one of the two enzymes (OMP decarboxylase) affected by the gene is reduced by about three-fold in mutant homozygous strains (Krooth, '64b). The specific activity of the cell protein for this enzyme is not affected by purines or purine ribosides in the case of normal and heterozygous cells.

When cell strains of any genotype are grown in the presence of certain inhibitors of UMP synthesis, they develop increased levels of activity for both the enzymes affected by the mutant gene (Pinsky and Krooth, '67a,b; Wuu and Krooth, '68; Krooth, '69b, '70). The inhibitors are barbituric acid, 5-azaorotic acid, and 6-azauridine. The first two of these compounds are specific and competitive inhibitors of, respectively, the third and fourth enzymes of the UMP sequence. ${ }^{8}$ The metabolic derivative of 6-azauridine, 6-azauridine-5'monophosphate, is a competitive inhibitor of the final enzyme of the sequence (OMP decarboxylase). It now seems likely, however, that all these compounds, not just 6-azauridine, are converted by the cell to the corresponding ribotide which in turn inhibits OMP decarboxylase - the final enzyme of UMP synthesis (Cihak and Sorm, '67; Cihak, Vesely and Sorm, '68; $\mathrm{Ma}$ and Krooth, '70).

When cells are grown in the presence of one of these inhibitors and the product of the pathway, as uridine or cytidine, the inhibitor has no effect on growth. However, the cells increase their specific activity for the final two enzymes of the sequence but not for at least two of the enzymes which act earlier (Pinsky and Krooth, '67a,b; Wuu and Krooth, '68). The increase in specific activity is frequently over 100 -fold in the case of mutant homozygous strains (Krooth, '69b), which develop heterozygous or normal levels of activity for both affected enzymes. In the case of normal and heterozygous cells, the absolute level of increase in specific activity for the two enzymes is somewhat greater than in the case of mutant homozygous cells, but the proportionate increase is considerably less (Krooth, '69b).

The mechanism by which these inhibitors stimulate cells to develop increased levels of enzyme activity is unknown. However, the present evidence suggests that they act, at least in part, by causing an intermediate in the pathway - perhaps orotic acid - to accumulate inside the cell. This intermediate, in turn, is likely to be the active molecule which induces or stabilizes the two enzymes affected by the gene (Krooth, '69b, '70). In Saccharomyces ceversiae, the final three enzymes of the sequence are induced or stabilized by the substrate of the first of these enzymes dihydroorotic acid (Lacroute, '68).

The reason two enzymes are affected in orotic aciduria is not known. In one reported patient, only the final enzyme is affected (Fox, O'Sullivan and Firkin, '69). However, the other cases have invariably been deficient in both OMP pyrophosphorylase and OMP decarboxylase. One possibility is that the two catalytic activities reside in a single protein. However, this seems unlikely, for at least in the case of calf thymus, the activities can be separated by starch gel electrophoresis (Kasbekar, Nagabhushanam and Greenberg, '64). Among the other possibilities would be

8 These enzymes are dihydroorotic acid dehydrogenase and orotidine-5'-monophosphate pyrophosphorylase (fig. 2 ). 
that the two enzymes are encoded in a single operon (Fallon et al., '63; Krooth, '64) - if indeed such genetic units exist in eucaryotic cells. Alternatively, the two enzymes might each contain an identical subunit whose structure was affected by the mutant gene. A fourth, and in some ways attractive possibility, is that the two enzymes are normally aggregated into a multimolecular complex. Such complexes uniting the enzymes of a single metabolic sequence, have frequently been observed in eucaryotic cells (Reed and Oliver, '68; Gross, '69; Fink, '70). In these organisms, a mis-sense mutation in one enzyme sometimes affects the catalytic activity of the complex for a number of enzymes (cf. Fink, '70). The advantage of such complexes for the cell is believed to be related to the fact that the complexes are theoretically capable of channeling metabolic intermediates. Intermediates can be directed towards subsequent enzymes in the metabolic sequence, which form part of the aggregate, rather than released after each reaction to diffuse throughout the cell (Davis, '67; Reed and Oliver, '68; Gross, '69; Fink, '70). In the case of human cells, precursors in the UMP pathway might tend to stabilize an aggregate containing the final two enzymes of the sequence; the effect might be particularly pronounced if the aggregate were abnormally unstable because of the inclusion of a mutant enzyme among its component molecules. Another possible pathogenesis for orotic aciduria, in which we have been especially interested, is as follows: As noted above, the evidence suggests that cells of all genotypes develop increased levels of activity for the two enzymes affected by the gene in response to the accumulation inside the cell of an intermediate in the pathway. The mutant gene might, therefore, act by affecting a cellular enzyme which normally confers upon the cell the ability to retain an intermediate (Krooth, '70). Such enzymes, affecting intermediates in the UMP pathway, apparently exist in eucaryotic forms (Lacroute, '68). On this view, the deficiency in the two enzymes of UMP synthesis would not be the primary biochemical lesion. Rather, the diffusion of intermediate out of the cell would lead to pyrimidine starvation, and, secondarily, to low levels of the final enzymes of the UMP sequence. Indeed, there are reasons for suspecting that some differentiated mammalian cells may normally liberate intermediate for the use of the cells around them (Krooth, '69b).

\section{d. Xeroderma pigmentosa}

Xeroderma pigmentosa (Rook and Wells, '68) is an autosomal recessive disease characterized by photophobia, hypertrophic changes in the skin, and frequently skin cancer. Affected persons develop unusually severe freckling and other disagreeable skin changes when they are exposed to sunlight. Dermatology textbooks (Lewis, '52) state that the destructive wavelengths for these patients are in the ultraviolet range.

Diploid cell strains from persons who are mutant homozygous are unusually sensitive to ultraviolet light (Gartler, '64). Biochemical studies reveal that, following UVexposure, the mutant homozygous cell cultures release an abnormally small proportion of their total DNA into the acid-soluble cellular pool (Cleaver, '68; Setlow et al., '69). It is possible, therefore, that the mutation affects an endonuclease which excises segments of DNA containing thymine dimers (Setlow et al., '69). Photoreactivation - or "dark repair" - involving the chemical repair of thymine dimers in situ does occur in mammalian cells (Painter, '70). Hence, it is almost certain that in this disease, the mechanism of excision repair is disturbed.

This disorder, incidentally, had until recently been considered a skin disease although in some patients, who have had extensive exposure to sunlight, the cornea and other external tissues of the eye became involved. The cell culture studies suggest that the skin is primarily affected because it is the only tissue normally exposed to ultraviolet light.

\section{e. The single active $\mathrm{X}$-theory}

The single active $\mathrm{X}$-theory (Lyon, '68) in its simplest form is based on the following premises :

1. Each female mammalian zygote contains two X-chromosomes - one derived from the father and the other from the mother. 
2. Early in development one X-chromosome in each female cell becomes inactive. The inactive $X$ does not function, although it continues to replicate when the cell divides.

3. The maternal and paternal X-chromosome have an equal probability of being the inactive one in any given cell.

4. The particular X-chromosome inactivated in a cell continues to be inactive in all the descendants of that cell.

These premises generate two predictions about the behavior of diploid cell strains developed from females who are heterozygous for X-linked genes.

'1. Mass cultures should consist of two cellular populations. One population of cells should resemble the wild-type and the other should resemble cells from mutant homozygous females or from mutant hemizygous males.

2. When mass cultures are cloned, two types of colonies should be recovered in about equal proportions: colonies whose cells have the mutant phenotype and colonies whose cells have the normal phenotype. There should not be any mixed colonies.

The second prediction seems, on the face of it, to be more strict than the first. However, the first prediction contains two assumptions which are not included in the second prediction. The first assumption is that one has a method - say autoradiography or histochemistry - for determining the phenotype of individual cells. The second assumption is that cellular phenotype is autonomous in the sense of not being influenced by the phenotype of other cells which are adjacent or in the same container. Both predictions assume that neither of the two cell types postulated by theory has been eliminated by selection in vivo or in vitro. This latter possibility means that finding only one kind of cell in mass culture or only one kind of colony after cloning does not necessarily invalidate the theory. Finding both phenotypes in a single clone is disastrous for the theory. The two predictions are critical, of course, only if one does not find a dimorphism in cell strains developed from hemizygous males or homozygous females.

Table 2 summarizes the work thus far done to test these predictions. The experi- ments have used a total of five sex-linked genes which are probably at three different loci. In every case so far, at least the second prediction has been met. When tested, the first prediction was also satisfied in one case, and an ambiguous result was obtained in another. It has also been shown that the second prediction is not met in the case of five autosomal genes tested. In other words, clonal cell populations from females heterozygous for each of these genes displayed the heterozygous phenotype in every case. The mutant genes were the ones causing electrophoretic variants of phosphoglucomutase (Davidson et al., '65; Sigman and Gartler, '66), lactic acid dehydrogenase (Davidson et al., '66) and 6-phosphogluconic acid dehydrogenase (Davidson et al., '66); the other mutant genes were the ones causing branched chain ketonuria (Sigman and Gartler, '66), and Hurler's syndrome (Danes and Bearn, '67a).

The data described above are, in aggregate, the strongest evidence yet collected to show that the single active X-theory is true, or at least that it applies to cultured diploid human cells for the loci studied. Whether the inactivation is absolutely complete and whether it applies to all loci are questions which are presently under study in a number of laboratories.

\section{Some of the uses of genetically marked human diploid cell strains}

Genetically marked human cell strains, like genetically marked strains of $E$. coli, have proven useful in the study of genetic change. The human diploid strains have been employed to demonstrate somatic cell hybridization (Weiss and Green, '67; Silagi, Darlington and Bruce, '69; Siniscalco et al., '69), the latter report showing that two such strains will hybridize with one another. Hopefully, a way will eventually be found to use human-human somatic cell hybrids for obtaining information about genetic linkage in man. Thus far, only mouse-human somatic cell hybrids have been employed for this purpose (Boon and Ruddle, '69; Klebe, Chen and Ruddle, '70; inter aliae).

Gene mutation also appears to have been detected in human diploid strains (Alber- 
TABLE 2

Experimental tests, using heterozygous human diploid cell strains of the single active $x_{\text {-theory }}{ }^{1}$

\begin{tabular}{|c|c|c|c|c|}
\hline \multirow[b]{2}{*}{ Mutant phenotypes } & \multicolumn{2}{|c|}{ Results } & \multirow[b]{2}{*}{$\begin{array}{l}\text { Predic- } \\
\text { tion } 1\end{array}$} & \multirow[b]{2}{*}{$\begin{array}{l}\text { Predic- } \\
\text { tion } 2\end{array}$} \\
\hline & $\begin{array}{l}\text { Predic- } \\
\text { tion 1 } \\
\text { (cellular } \\
\text { dimor- } \\
\text { phism) }\end{array}$ & $\begin{array}{l}\text { Predic- } \\
\text { tion 2 } \\
\text { (clonal } \\
\text { dimor- } \\
\text { phism) }\end{array}$ & & \\
\hline $\begin{array}{l}\text { Glucose-6-phosphate dehydrogenase } \\
\text { deficiency (Mediterranean variety) }\end{array}$ & -2 & + & - & $\begin{array}{c}\text { Davidson, } \\
\text { Nitowsky and } \\
\text { Childs } \\
\text { ('63) }\end{array}$ \\
\hline $\begin{array}{l}\text { B-Variant of glucose-6-phosphate } \\
\text { dehydrogenase }\end{array}$ & - & + & - & $\begin{array}{l}\text { Davidson, } \\
\text { Nitowsky and } \\
\text { Childs } \\
\text { ('63) }\end{array}$ \\
\hline $\begin{array}{l}\text { Madison variant of glucose-6-phosphate } \\
\text { dehydrogenase }\end{array}$ & - & + & - & $\begin{array}{l}\text { DeMars and } \\
\text { Nance ('64) }\end{array}$ \\
\hline $\begin{array}{l}\text { Hurler's syndrome (tissue culture } \\
\text { phenotype: cellular metachromasia) }\end{array}$ & $?^{3}$ & + & $\begin{array}{c}\text { Danes and } \\
\text { Bearn } \\
\text { ('66) }\end{array}$ & $\begin{array}{c}\text { Danes and } \\
\text { Bearn } \\
\text { ('67) }\end{array}$ \\
\hline $\begin{array}{l}\text { Lesch-Nyhan syndrome (tissue culture } \\
\text { phenotype: absence of hypoxanthine: } \\
\text { guanine phosphoribosyltransferase } \\
\text { and failure of individual cells to incor- } \\
\text { porate }{ }^{3} \mathrm{H} \text {-guanine or }{ }^{3} \mathrm{H} \text {-hypoxanthine } \\
\text { into acid-insoluble material) }\end{array}$ & + & + & $\begin{array}{l}\text { Rosenbloom } \\
\text { et al. } \\
\text { ('67) }\end{array}$ & $\begin{array}{l}\text { Migeon } \\
\text { et al. } \\
\text { ('68) }\end{array}$ \\
\hline
\end{tabular}

1 The definition of the symbols is as follows: + , denotes prediction was found to apply to the specified gene; 0 , denotes prediction was found not to apply to the specified gene; $\rightarrow$, denotes prediction has not yet been tested.

2 A histochemical method for determining cellular phenotype, with respect to this gene, has recently been developed by Wajntal and DeMars ('67). Hence, it should be possible to test Prediction 1 in this case almost at once.

3 The results for this locus are difficult to interpret. About half the cells of female heterozygotes have the metachromatic granules characteristic of the mutant hemizygous genotype. However, cells from one hemizygous male showed a similar dimorphism in mass culture, which seems to vitiate the theoretical significance of the observation on female cells. Nearly all the cells of two other hemizygous males who were studied contained the granules.

tini and DeMars, '70). It seems likely that other phenomena, such as transduction and DNA-mediated genetic transformation, will eventually be demonstrated with these cells.

The potential value of human diploid cell strains in genetic analysis is very great, partly because the biology of the cells suggests that they are more likely than heteronuclear cells to reveal the normal properties of the human cell, and partly because of their chromosomal stability. However, the main advantages of diploid cell strains for genetic analysis arise from the fact that the strains can be isolated from virtually any donor.

Perhaps the most dramatic present use of diploid cell strains is in the antenatal diagnosis of hereditary disease. The cultivation of the cells recovered from amniotic fluid during the first trimester of preg- nancy usually yields a diploid strain of fetal origin. This strain can then be used, in the case of many loci, to infer the biochemical phenotype of the fetus (Jacobson and Barter, '67; Nadler, '69; Nadler and Gerbie, '69; Littlefield, '70; Emery, '70; inter aliae). If the cellular phenotype indicates that the fetus is abnormal, the parents may wish, in certain circumstances, to have the pregnancy aborted. In some states, abortion on these grounds is legally permissible. Antenatal diagnosis of biochemical disorders has been used primarily in cases where a high risk of a severe genetic abnormality is inferred either from previous pregnancies in the family or from the results of studies on the somatic tissues of the parents.

This technique represents an unusual application of cell genetics to clinical medicine, and is likely to be widely prac- 
ticed in the years ahead. Its social, moral and genetic implications are already the object of considerable discussion.

Another possible use of genetically marked diploid cell strains is the study of complementation. By the technique of somatic cell hybridization or simply by the formation of heterokaryocytes, it should sometimes be possible to determine whether two human mutations, affecting the same enzyme or cellular process, will complement (Velazquez, '70). Information on this point may occasionally be useful in genetic counselling. It should also help considerably in understanding the precise mode of action of individual human genes.

Cultured homonuclear cells have several other potential uses in diagnosis. For one thing, it is feasible to grow cells from a patient with an unknown metabolic defect in both minimal and complete tissue culture media (Krooth, '66b). If the cells grow in the complete medium but not in the minimal one, it should then be possible (in at least some cases) to infer which molecule the cells need. This can be done by testing the known molecules which the complete medium contains and the minimal medium does not - a procedure that is commonplace in microbial genetics. If the molecule is identified, the result will suggest not only the probable metabolic location of the biochemical lesion but also the appropriate therapy. In actual fact, however, no new genetic abnormalities have been clearly diagnosed in this way though several attempts have been made (Krooth, '66b). This approach to diagnosis is likely to be worth exploring further.

Another use of cultured human cells is related to the fact that they can be grown on a large scale. Today it is quite feasible (though neither easy nor cheap) to produce between 300 and $600 \mathrm{gm}$ of cells from only a minute biopsy. Clearly, most patients, especially pediatric ones, would be in no position to forfeit so much tissue for diagnostic purposes. This quantity of cells should yield between 50 and $100 \mathrm{gm}$ of protein - all presumably biosynthesized according to information the patient inherited. One hundred grams of protein should be sufficient to purify to homogeneity many enzymes of the cell, and to analyze their tryptic peptides. In a few in- stances, it may even be sufficient to enable one to determine the amino acid sequence of the protein. Hence, it should be possible in some cases to determine precisely what is wrong with the affected enzyme. Fortunately, most of the therapeutic methods now in use in the treatment of genetic diseases do not require such detailed information about the affected enzyme. However, as our approaches to therapy become more subtle and powerful, that situation could change.

\section{Problems for the future}

In this review, we have been mainly concerned with gene action in human diploid cell strains. The cells of such strains, like all normal somatic cells, are presumed to contain the complete human genome. Yet only a fraction of the loci are expressed. If we could compel the cultured human cell to display its phenotype at any specified locus in response to a defined signal, we would be in a far better position to apply the technique of cell culture to both scientific and practical problems.

For example, we could greatly increase the number of loci to which the method of antenatal diagnosis might be applied. Even more important, perhaps, the clinician would have a way of evoking the appearance in cultured fibroblasts of enzymes normally found only in inaccessible organs such as brain or liver. It is not always easy to defend - morally and legally - the biopsy of an intra-abdominal or intra-cranial structure for genetic studies. Even if the tissue is removed for the purpose of diagnosis on the person biopsied, it would be better to assay the enzyme or protein in cultured cells from a skin specimen than to remove tissue from an internal organ - a procedure that is always associated with some risk. Moreover, once the clinician has the fibroblasts he can do microbiological studies which would not be feasible with a whole patient or a fragment of tissue. Hence, the number of hereditary diseases that can be studied by the microbiological methods would be greatly increased. In addition, cell lines which synthesized many human tissuespecific molecules would probably prove extremely useful in the manufacture of 
pharmaceuticals (Tashjian, '69) such as growth hormone for which there is at present no satisfactory natural source. Finally, it would be extremely valuable to be able to study the molecular events that occur when a cell is stimulated to initiate the synthesis of a tissue-specific protein it has not previously synthesized. A study of these events might well reveal much about the molecular mechanism which underlies cell differentiation.

Of course, if we thoroughly understood the mechanism for cell differentiation in the first place, we would probably be able to guess the chemical nature of the stimuli which are capable of activating unexpressed loci. In the absence of such knowledge, how can we try to identify the signals to which the cell will respond? First, of course, one must postulate that chemical stimuli of this kind exist and can be identified. Given those assumptions, however, how does one proceed in the absence of any further information?

We should like to summarize from two approaches that we have been interested in.

The first approach is to select a tissuespecific enzyme which has the following properties :

1. The catalytic activity is normally absent from human diploid cell strains.

2 . The catalytic activity is normally absent - or present in only trace amounts - in the cells of a eucaryotic fungus (preferably a higher filamentous fungus).

3. The catalytic activity is inducible in the fungus by a known molecule.

The experiment then is simply to challenge the human diploid cells with the inducer identified for the fungus cells. By challenge, I mean not only to expose the human cells to the fungal inducer but to ensure that the inducer gets inside them. It is not unreasonable to suspect that eucaryotic cells capable of differentiating may respond similarly to the same stimulus.

Dr. Horst Brunschede ${ }^{\circ}$ and one of us (R. S. K.) have noticed that the enzyme xanthine oxidase satisfies the three criteria listed above. Catalytic activity for this enzyme is found in appreciable amounts only in liver and gastrointestinal mucosa (Watts, Watts and Seegmiller, '65). No activity, even with very sensitive assays, has been found in cultured human fibroblasts (Watts, Watts and Seegmiller, '65; Seegmiller, '69). Extremely low levels of this enzyme can be detected in Aspergillus nidulans. In this organism, however, cells can be induced to develop high levels of xanthine oxidase by uric acid, the product of the enzyme (Scazzochio and Darlington, '68). Indeed, the control of this enzyme in Aspergillus appears to resemble one of the "circuits" suggested by Monod and Jacob ('61) for the regulation of enzymes in differentiated cells. Dr. Brunschede is presently attempting to determine whether very high intracellular levels of uric acid will induce xanthine oxidase in human diploid cell strains.

A second approach involves the technique of somatic cell hybridization. In several reported experiments, hybrids have been formed between a cell line which performs a known tissue-specific function and a cell line which does not perform that function. In every instance, the hybrid clones have failed to perform the function studied (Davidson, Ephrussi and Yamamoto, '66; Finch and Ephrussi, '67; Sonnenschein, Tashjian and Richardson, '68). Hence, it has been argued that the cell line which fails to perform the tissuespecific function may synthesize a diffusible "repressor" of the function (Davidson and Yamamoto, '68). Certainly, this possibility is the simplest (but by no means the only) explanation for the fact that tissuespecific functions have so far acted like "recessive" attributes in somatic cell crosses. There are now methods which should work for back-crossing a hybrid cell line (Darlington, '70) against the parental line which performs the tissue-specific function. Moreover, it should be possible to repeat the process - again to back-cross the hybrid which resulted from a backcross against the cell line which performs the tissue-specific function. If the process can be repeated for a sufficient number of cycles, it may be possible to "titrate" the theoretical repressor by introducing into the hybrid cell successive doses of those genes which cause the cell autonomously to perform the tissue-specific function. Eventually - if the idea of a repressor is

9 Of the Department of Human Genetics, University of Michigan Medical School. 
correct - the hybrid might perform the tissue-specific function. Such an $\mathbf{n}^{\text {th }}$ order hybrid cell could be a most useful reagent. If the cell indeed performed the function, then it might prove possible to cross the $\mathbf{n}^{\text {th }}$ order hybrid (or a higher order one) with a diploid cell strain from any random donor and obtain a line which made the tissue-specific product biosynthesized according to the genome of the donor of the strain. Such a line would of course also synthesize the product according to the genome it contained prior to being crossed with the diploid strain. However, if the $\mathbf{n}^{\text {th }}$ order hybrid were formed from a nonhuman species, it should in many cases be possible chemically to resolve the two products.

If the above experiment is to work, certain assumptions must be true. The failure of the hybrid to perform a tissue-specific function must indeed be due to a "diffusible" repressor - a repressor that acts on the genome that originally contained it as well as on the genome that did not. The number of repressor molecules per cell must be relatively small. It would not be feasible to try to make 10,000 successive back-crosses. Other assumptions are also necessary.

However, the point of this discussion is that experiments aimed at developing lines of cultured cells which synthesize tissuespecific products according to the genomes of individual human donors are already feasible. The potential value of such lines if they could be developed is enormous.

The initial difficulty in the use of human diploid fibroblasts for genetic studies was the failure of the cells to display their phenotype at most loci. Despite the remarkable discoveries of the past ten years, this difficulty persists. Its solution - if it can be solved - would be an enormous advance.

\section{CONCLUSION}

Some of the cells of every human being will grow outside the body as microorganisms. It is possible to show, in a variety of ways, that these cells resemble genetically the individual from whom they were obtained. Over 35 inherited human diseases and anomalies can now be studied in such cell lines.
Human diploid cell strains, biochemically marked by one or more mutant Mendelian genes, have proven particularly useful for the study of gene action in man and for the detection of genetic changes such as mutation and somatic cell hybridization. In addition, the strains have a number of clinical applications, including the antenatal diagnosis of inherited disease.

The failure of cultured human cells to display their phenotype at most loci continues to restrict their use in both genetics and medicine. There are reasons for hoping that this difficulty will eventually be solved, and some experiments bearing on the problem are already feasible.

\section{LITERATURE CITED}

Alberini, R. J., and R. DeMars 1970 Diploid azaguanine resistant mutants of cultured human fibroblasts. Science, in press.

Bayreuther, K. 1964 Technical problems. In: Somatic Cell Genetics. R. S. Krooth, ed. Fourth Conference on Genetics. Josiah Macy, Jr. Foundation. Univ. of Mich. Press, Ann Arbor, Michigan. $301 \mathrm{pp}$.

Boone, C. M., and F. H. Ruddle 1969 Interspecific hybridization between human and mouse somatic cells: enzyme and linkage studies. Biochem. Genet., 3: 119-136.

Brockman, R. W., G. G. Kelley, P. Stutts and V. Copeland 1961 Biochemical aspects of resistance to 6-mercaptopurine in human epidermoid carcinoma cells in culture. Nature, 191: $469-471$.

Choi, K. W., and A. D. Bloom 1970 Biochemically marked lymphocytoid lines: establishment of Lesch-Nyhan cells. Science, in press.

Cihak, A., and F. Sorm 1967 Metabolic transformation of 5-azaorotale: cause of marked inhibition of orotidine-5'-monophosphate decarboxylase. Biochim. Biophys. Acta, 149: 314-316.

Cihak, A., J. Vesely and F. Sorm 1968 Inhibition of pyrimidine biosynthesis by 5-azaorotate in mouse liver. Collection Czechoslov. Chem. Commun., 33: 1778-1787.

Cleaver, J. 1968 Defective repair replication of DNA in xeroderma pigmentosum. Nature, 218: 652-656.

Conover, J. H., P. Hathaway, P. R. Glade and K. Hirschhorn 1970 Persistence of phosphoglucomutase (PGM) polymorphism in long-term lymphoid lines. Proc. Soc. Exp. Biol. Med., 133: 750-753.

Danes, S., and A. Bearn 1966 Hurler's syndome: a genetic study in cell culture. J. Exp. Med, 123: 1-16.

1967 Hurler's syndrome: a genetic study of clones in cell culture with particular reference to the Lyon hypothesis. J. Exp. Med., 126: 509-522.

Darlington, G. A. J. 1970 Studies of mixed cultures of human somatic cells. Ann Arbor, Michigan, University of Michigan. Ph.D. Thesis. 
Davidson, R. G., A. M. Glen-Bott and H. Harris 1965 Clonal study of three autosomal loci in heterozygotes. Amer. Soc. Human Genet. Abstracts. Abstract 45, p. 35: Annual Meeting of 25-27 August 1965.

Davidson, R. G., H. M. Nitowsky and B. Childs 1963 Demonstration of two populations of cells in the human female heterozygous for glucose-6-phosphate dehydrogenase variants. Proc. Nat. Acad. Sci., 50: 481-485.

Davidson, R. L., B. Ephrussi and K. Yamamoto 1966 Regulation of pigment synthesis in mammalian cells, as studied by somatic hybridization. Proc. Nat. Acad. Sci., 56: 1437-1440.

Davidson, R. L., and K. Yamamoto 1968 Regulation of melanin synthesis in mammalian cells, as studied by somatic hybridization. II. The level of regulation of 3,4 ,-dihydroxyphenylalanine oxidase. Proc. Nat. Acad. Sci., 60: 894901.

Davis, R. 1967 Channeling in Neurospora metabolism. In: Organizational Biosynthesis. H. J. Vogel, J. O. Lampen and V. Bryson, eds. Academic Press Inc., New York, pp. 303-322.

DeMars, R., and J. L. Hooper 1960 A method for selecting for auxotrophic mutants of HeLa cells. J. Exp. Med., 111: 559-572.

DeMars, R., and W. E. Nance 1964 Electrophoretic variants of glucose-6-phosphate dehydrogenase and the single active $X$. In: Retention of Functional Differentiation in Cultured Cells. V. Defendi, ed. Wistar Institute Press, Philadelphia, Pennsylvania. 116 pp. (pp. 3548).

Emery, A. E. H. 1970 Antenatal diagnosis of genetic disease. In: Modern Trends in Human Genetics. A. E. H. Emery, ed. Vol. 1, 267-296.

Fahey, J. L., I. Finegold, A. S. Rabson and R. A. Manaker 1966 Immunoglobulin synthesis in vitro by established human cell lines. Science, 152: 1259-1261.

Fallon, H. J., L. H. Smith, Jr., M. Lotz, J. B. Graham and C. H. Burnett 1963 Hereditary orotic aciduria. Trans. Assoc. Amer. Phys, 76: 214.

Felix, J. S., and R. DeMars 1969 Purine requirement of cells cultured from humans affected with Lesch-Nyhan syndrome (hypoxanthine-guanine phosphoribosyltransferase deficiency). Proc. Nat. Acad. Sci., 62: 536-543.

Finch, B., and B. Ephrussi 1967 Retention of multiple developmental potentialities by cells of a mouse testicular teratocarcinoma during prolonged culture in vitro and their extinction upon hybridization with cells of permanent lines. Proc. Nat. Acad. Sci., 57: 615_621.

Fink, G. R. 1970 Gene clusters and the regulation of biosynthetic pathways in fungi. Metabolic Pathways. Academic Press, New York, in press.

Fox, R. M., W. J. O'Sullivan and B. G. Firkin 1969 Orotic aciduria; differing enzyme patterns. Amer. J. Med., 47: 332-336.

Fratantoni, J. C., C W. Hall and E. F. Newfeld 1968 Hurler and Hunter syndromes: mutual correction of the defect in cultured fibroblasts. Science, 162: 570-572.
1969 The defect in Hurler and Hunter syndromes. II. Deficiency of specific factors involved in mucopolysaccharide degradation. Proc. Nat. Acad, Sci., 64: 360-366.

Friedman, T., J. E. Seegmiller and J. H. Subak Sharpe 1969 Evidence against the existence of guanosine and inosine kinases in human fibroblasts in tissue culture. Exp. Cell Res., 56: 425-429.

Gartler, S. 1964 Inborn errors of metabolism at the cell culture level. In: Second International Conference on Congenital Malformations. M. Fishbein, ed. International Medical Congress Ltd., New York, 442 pp. (pp. 94-102).

1967 Genetic markers as tracers in cell culture. Nat. Cancer Inst. Monog., 26: 167-195.

Green, H., B. Goldberg and G. J. Todaro 1966 Differentiated cell types and the regulation of collagen synthesis. Nature, 212: 631-633.

Green, H., and G. J. Todaro 1963 Growth potential of mammalian cell strains. Proceedings of Symposium on the Characterization and Uses of Human Diploid Cell Strains. International Association of Microbiological Societies, Opatija, Zagreb, pp. 209-220.

Green, M. L., J. A. Boyle and J. E. Seegmiller 1970 Substrate stabilization: genetically controlled reciprocal relationship of two human enzymes. Science, 167: 887-889.

Gross, S. R. 1969 Genetic regulatory mechanisms in the fungi. Ann. Rev. Genetics, 3: 395424.

Harris, H. 1966 Enzyme polymorphisms in man. Proc. Royal Soc. London, 164: 293-310.

Henderson, J. F., F. M. Rosenbloom, W. N. Kelley and J. E. Seegmiller 1968 Variations in purine metabolism of cultured skin fibroblasts from patients with gout. J. Clin. Investig., 47: 1511-1516.

Herzenberg, L, A. 1964 Technical Problems. In: Somatic Cell Genetics. R. S. Krooth, ed. Fourth Conference on Genetics. Josiah Macy, $\mathrm{Jr}$. Foundation. Univ. of Mich. Press, Ann Arbor, Michigan. 301 pp. (p. 132).

Howell, R. R., J. R. Klinenberg and R. S. Krooth 1967 Enzyme studies on diploid cell strains developed from patients with hereditary orotic aciduria. Johns Hopkins Med. J., 120: 81-88.

Isselbacher, K. J. 1966 Galactosemia. In: The Metabolic Basis of Inherited Disease. J. B. Stanbury, J. B. Wyngaarden and D. S. Fredrickson, eds. McGraw-Hill Book Co., New York, 1434 pp. (p. 178-188).

Jacobson, C. B., and R. H. Barter 1967 Intrauterine diagnosis and management of genetic defects. Amer. J. Obstet. Gynec., 99: 796-807.

Justice, P., C. Ryan, E. Krompotic and D. Y. Y, Hsia 1969 Program and Abstracts of the American Society of Human Genetics, Abstract 57, San Francisco, California, Oct. 1-4.

Kaback, M., and R. R. Howell 1970 Infantile metachromatic leukodystrophy. New Eng. J. Med., 282: 1336-1340.

Kao, F. K., and T. T. Puck 1968 Genetics of somatic mammalian cells. VII. Induction and isolation of nutritional mutants in Chinese 
hamster cells. Proc. Nat. Acad. Sci., 60: 12751281 .

Kasbekar, D, K., A. Nagabhushanam and D. Greenberg 1964 Purification and properties of orotic acid-decarboxylating enzymes from calf thymus. J. Biol. Chem., 239: 4245-4249.

Kelley, W. N., M. L. Greene, F. M. Rosenbloom, F. J. Henderson and J. E. Seegmiller 1969 Hypoxanthine guanine phosphoribosyltransferase deficiency in gout. Ann. Int. Med., 70: 155206.

Kelley, W. N., F. M. Rosenbloom, J. F, Henderson and J. E. Seegmiller 1967 A specific enzyme defect in gout associated with overproduction of uric acid. Proc. Nat. Acad. Sci., 57: 1735-1739.

Klebe, R. J., T. Chen and F. H. Ruddle 1970 Controlled production of proliferating somatic cell hybrids. J. Cell Biol., 45: 74-82.

Krooth, R. S. 1964a Study of galactosemia, acatalasemia and other human metabolic mutants in cell culture. In: Somatic Cell Genetics. R. S. Krooth, ed. Fourth Macy Conference on Genetics. Univ, of Mich. Press, Ann Arbor, Michigan. pp. 167-194.

1964b Properties of diploid cell strains developed from patients with an inherited $a b$ normality of uridine biosynthesis. Cold Spring Harbor Symp. Quant. Biol., 29: 189-212. 1965 The future of mammalian cell genetics. Birth Defects. (Original Article Series) 1: 21-56.

1966a Some properties of diploid cell strains developed from the tissues of patients with inherited biochemical disorders. In Vitro, 2: 82-96.

_ 1966b Diploid cell strains from patients with inherited biochemical abnormalities. Alabama J. Med. Sci., 3: 456-461.

- 1969a Genetics of cultured somatic cells. In: Medical Clinics of North America, 53: $795-811$.

- 1969b Gene action in diploid cell strains. In: Comparative Mammalian Cytogenetics. K. Benirschke, ed. Springer-Verlag, New York, pp. 154-179.

1970 Studies bearing on the regulation of uridine-5'-monophosphate biosynthesis in human diploid cells. In: Control Mechanisms in Expression of Cellular Phenotypes. H, Padykula, ed. Academic Press, New York, in press.

Krooth, R. S., and G. A. Darlington 1968 The genetics of cultured mammalian cells, Ann. Rev. Genetics, 2: 141-164.

Krooth, R. S., and A. N. Weinberg 1961 Studies on cell lines developed from the tissues of patients with galactosemia. J. Exp. Med,, 113: 1155-1172.

Lacroute, F. 1968 Regulation of pyrimidine biosynthesis in Saccharomyces cerevisiae. J. Bacteriol., 95: 824-832.

Lewis, G. M. 1952 Practical Dermatology. W. B. Saunders Co., Philadelphia, Pennsylvania. $328 \mathrm{pp}$.

Lewontin, R. C. 1967 An estimate of average heterozygosity in man. Amer. J. of Human Genetics, 19: 681-685.
Littlefield, J. 1970 The pregnancy at risk for a genetic disorder. New England J. Med., 282: 627-628.

Lyon, M. 1968 Chromosomal and subchromosomal inactivation. Ann. Rev. Genetics, 2: 3153.

Ma, R., and R. S. Krooth 1970 Unpublished observations.

Mayes, J. S., and R. Guthrie 1968 Detection of heterozygotes for galactokinase deficiency in a human population. Biochemical Genetics, 2: 219-230.

Migeon, B. R., U. M. der Kaloustian, W. L. Nyhan, W. J. Young and B. Childs 1968 X-linked hypoxanthine-guanine phosphoribosyltransferase deficiency: heterozygote has two clonal populations. Science, 160: 425-427.

Monod, J., and F. Jacob 1961 General conclusions: telonomic mechanisms in cellular metabolism, growth, and differentiation. Cold Spring Harbor Symp, Quant. Biol., 26: 389-401.

Moore, G. E., and W. F. McLimans 1968 The life span of the cultured normal cell. Concepts derived from studies of human lymphocytes. J, Theoret. Bìl., 20: 217-226.

Moore, G. E., I. H. Porter and C. C. Huang 1969 Lymphocytoid lines from persons with sex chromosome anomalies. Science, 163: 14531454.

Nadler, H. L. 1969 Antenatal detection of hereditary disorders. Pediatrics, 42: 912-918.

Nadler, H. L., and A. B. Gerbie 1970 Role of amniocentesis in the intra-uterine detection of genetic disorders. New England J. Med., 282: 596-599.

Neufeld, E. F., and J. C. Fratantoni 1970 Inborn errors of mucopolysaccharide metabolism. Science, 169: 141-146.

Nyhan, W. L., J. Pesek, L. Sweetman, D. G. Carpenter and C. H. Carter 1967 Genetics of an $\mathrm{X}$-linked disorder of uric acid metabolism and cerebral function. Pediat. Res., 1: 5-13.

O'Brien, J. S., and S. Okada 1969 Tay-Sachs disease: generalized absence of a beta-D-Nacetyl hexosaminidase component. Science, 165: 698-700.

O'Brien, J. S., S. Okada, M. W. Ho, D. L. Fillerup, N. L. Veath and K. Adams 1970 Ganglioside storage diseases. Fed. Proc., in press.

Painter, R. B. 1970 Nonconservative replication of damaged DNA in mammalian cells. 23rd M. D. Anderson Symposium on Genetic Concepts and Neoplasia.

1970 The action of ultraviolet light on mammalian cells. Photophysiology, 5: in press.

Painter, R. B., and J. E. Cleaver 1967 Repair replication in HeLa cells after large doses of X-irradiation. Nature, 216: 369-370.

Payne, M. R., J. Dancis, P. H. Berman and M. E. Balis 1970 Inosine kinase in leukocytes of Lesch-Nyhan patients. Expt. Cell Res., 59: 489 490.

Pinsky, L, J. W. Callahan and L. S. Wolfe 1968 Fucosidosis. Lancet, $i i: 1080$.

Pinsky, L., and R. S. Krooth 1967a Studies on the genetic control of pyrimidine biosynthesis 
in human diploid cell strains. I. Effect of 6-azauridine on cellular phenotype. Proc. Nat. Nat. Acad. Sci., 57: 925-932.

$1967 \mathrm{~b}$ Studies on the control of pyrimidine biosynthesis in human diploid cell strains. II. Effects of 5-azaorotic acid, barbituric acid and pyrimidine precursors on cellular phenotype. Proc. Nat. Acad. Sci., 57: 1267-1274.

Pollack, R. E., H. Green and G. J. Todaro 1968 Growth control in cultured cells: selection of sublines with increased sensitivity to contact inhibition and decreased tumor-producing ability. Proc. Nat. Acad. Sci., 60: 126-133.

Reed, L. J., and R. M. Oliver 1968 The multienzyme $\alpha$-keto acid dehydrogenase complexes. Structure, Function, and Evolution of Proteins. Brookhaven Symp. Biol., 21: (part II): $397-$ 412.

Rook, A., and R. S. Wells 1968 Genetics in dermatology. In: Textbook of Dermatology. A. Rook, D. S. Wilkinson and F. G. Ebling, eds. Blackwell Scientific Publications, Oxford, England. Vol. I, 40-73.

Rosenberg, L. E., A. C. Lilljeqvist, Y. E. Hsia and F. M. Rosenbloom 1969 Vitamin $B_{12}$ dependent methylmalonic aciduria: defective $B_{12}$ metabolism in cultured fibroblasts. Biochem. Biophys. Res. Comm., 37: 607-614.

Rosenbloom, F. M., J. F. Henderson, I. C. Caldwell, W. N. Kelley and J. E. Seegmiller 1968 Biochemical bases of accelerated purine biosynthesis de novo in human fibroblasts lacking hypoxanthine-guanine phosphoribosyltransferase. J. Biol. Chem., 243: 1166-1173.

Rosenbloom, F. M., W. N. Kelley, J. F. Henderson and J. E. Seegmiller 1967 Lyon hypothesis and X-linked disease (Lesch-Nyhan Syndrome). Lancet, ii: 305-306.

Russel, J. D. 1969 Variation in UDPglu:alphaD-Gal-1-P uridyl transferase activity during growth of cultured fibroblasts. In: Glactosemia. D. Y. Y. Hsia, ed. Charles C Thomas, Springfield. 318 pp. (pp. 204-212).

Scazzochio, C., and A. J. Darlington 1968 The induction and repression of the enzymes of purine breakdown in Aspergillus nidulans. Biochim. Biophys. Acta, 166: 557-568.

Seegmiller, J. E. 1969 Diseases of purine and pyrimidine metabolism. In: Duncan's Diseases of Metabolism. P. K. Bondy and L. Rosenberg, eds. W. B. Saunders Co., Philadelphia. Vol. 1, 516-599 (6th Edition).

Seegmiller, J. E., F. M. Rosenbloom and W. N. Kelley 1967 Enzyme defect associated with a sex-linked human neurological disorder and excessive purine synthesis. Science, 155: 16821684.

Sell, E. K. 1970 Unpublished observations.

Setlow, R. B., J. D. Regan, J. German and W. L. Carrier 1969 Evidence that xeroderma pigmentosum cells do not perform the first step in the repair of ultraviolet damage to their DNA. Proc. Nat. Acad. Sci., 64: 1035-1041.

Shih, V. E., J. W. Littlefield and H. W. Moser 1969 Arginosuccinase deficiency in fibroblasts cultured from patients with arginosuccinic aciduria. Biochemical Genetics, 3: 81-84.
Sigman, B., and S. M. Gartler 1966 The absence of inactivation at two autosomal loci. Humangenetik, 2: 372-377.

Silagi, S., G. Darlington and S. A. Bruce 1969 Hybridization of two biochemically marked human cell lines. Proc. Nat. Acad. Sci., 62: 1085-1092.

Siniscalco, M., H. P. Klinger, H. Eagle, H. Koprowski, W. J. Fujimoto and J. E. Seegmiller 1969 Evidence for intergenic complementation in hybrid cells derived from two human diploid strains, each carrying an X-linked mutation. Proc. Nat. Acad. Sci., 62: 793-799.

Sloan, H. R., B. W. Uhlendorf, C. B. Jacobson and D. S. Frederickson 1969 B-galactosidase in tissue culture derived from human skin and bone marrow enzyme defect in $\mathrm{G}_{\mathrm{Mr}}$ gangliosidosis. Ped. Res., 3: 532-537.

Smith, L. H., C. M. Huguley and J. A. Bain 1966 Hereditary orotic aciduria. In: The Metabolic Basis of Inherited Disease. J. B. Stanbury, J. B. Wyngaarden and D. S. Frederickson, eds. McGraw-Hill Book Co., Inc., New York. 2nd Edition, 739-758.

Smith, L. H., M. Sullivan and C. M. Huguley, Jr. 1961 Pyrimidine metabolism in man. IV. Enzymatic defect of orotic aciduria. J. Clin. Invest., 40: 656-664.

Sonnenschein, C., A. H. Tashjian and V. I. Richardson 1968 Somatic cell hybridization: mouse-rat hybrid cell line involving a growth hormone-producing parent. Genetics, 60; 227228.

Szybalski, W., and E. H. Szybalska 1962 Drug sensitivity as a genetic marker for human cell lines. Univ. of Mich. Med. Bull, 28: 277-293.

Tashjian, A. H. 1969 Animal cell culture as a source of hormones. Biotechnology and Bioengineering, 11 : 109-126.

Tedesco, T. A., and W. J. Mellman 1967 Arginosuccinate synthetase activity and citrulline metabolism in cells cultured from a citrullinemic subject. Proc. Nat. Acad. Sci., 57: 829834.

1969 Galactose-1-phosphate uridyltransferase and galactokinase activity in cultured human diploid fibroblasts and peripheral blood leucocytes. J. of Clin. Inves., 48: 2390-2397.

Todaro, G. J., and H. Green 1963 Quantitative studies of the growth of mouse embryo cells in culture and their development into established cell lines. J. Cell Biol., 17: 299-313.

Uhlendorf, B. W, and R. Brady 1970 Personal communication.

Uhlendorf, B. W., and S. H. Mudd 1968 Cystathionine synthetase in tissue cultures derived from human skin: enzyme defect in homocystinuria. Science, 160: 1007-1009.

Velazquez, A. A. 1970 An experimental study of viral-induced cell fusion with special reference to human diploid cell strains. University of Michigan, Ann Arbor. Ph.D. Thesis.

Wagntal, A., and R. DeMars 1967 A tetrazolium method for distinguishing between cultured human fibroblasts having either normal or deficient levels of glucose-6-phosphate dehydrogenase. Biochem. Genetics, 1: 65-71. 
Watts, R. W. E., J. E. M. Watts and J. E. Seegmiller 1965 Xanthine oxidase activity in human tissue and its inhibition by allopurinol (4hydroxy-pyrazolo [3,4-d] pyrimidine). J. Lab. and Clin. Med., 66: 688-697.

Weiss, M. C., and H. Green 1967 Humanmouse cell lines containing partial complements of human chromosomes and functioning human genes. Proc. Nat. Acad. Sci., 58: 1104-1111.
Wiesmann, U., and E. F. Neufeld 1970 Scheie and Hurler Syndromes: apparent identity of the biochemical defect. Science, 169: 72-74.

Wolfe, L. S., J. Callahan, J. S. Fawcett, F. Andermann and C. R. Scriver $1970 \quad G_{M I}$-gangliosidosis without chondrodystrophy or visceromegaly. Neurology, 20: 23-44.

Wuu, K. D., and R. S. Krooth 1968 Dihydroorotic acid dehydrogenase activity of human diploid cell strains. Science, 160: 539-541. 